\section{PP-385裩色細胞睡に対する股腔鏡下手街の検 吋}

\section{千葉大学 医学部 泌尿器科" 横浜労災病院泌尿器科2?} 納谷幸男",市川智彦”, 哙木 啓悦", 植田 健 ${ }^{11}$ 戸辺 典钩", 五十嵐 辰男", 伊藤 晴夫" ${ }^{\prime \prime}$ 永田 真樹 ${ }^{21}$ 山口 邦雄 ${ }^{2 \prime}$

【目的】褐色細胞腫に対する腹腔鏡下副腎摘除術の有用性 につき, 検討する【方法】1994 年 4 月から， 2002 年 7 月 までに腹腔镜下副腎摘除術を施行した 165 例のうち，褐 色紐胞腫 20 例を対象とした。手術時間, 出血星, 術中血 圧につき検討を加えた。【成緇】 20 例ともに，腹腔鏡下に 手術を施行しえた。経後腹膜的到達法が 3 例, 経腹的到 達法が 17 例であった。どの症例もまず, 副腎静脈を処理 したのち，副腎を摘出した。内訳は左 10 例，右 10 例, 男 10 例, 女 10 例で, 平均年齡は 46.3 葴, 平均腫瘍径は $43.7 \mathrm{~mm}$ 。平均手術時間は 214 分, 平均出血量は $165 \mathrm{ml}$ であった。手術中の最高収縮期血圧は平均 $194 \mathrm{mmHg}$ (140mmHg-250mmHg) であった。合併症は認めなかっ た。歩行開始日は術後平均 1.9 日, 食事開始日は術後平均 2.4 日であった。結論】褐色細胞腫に対しても安全に腹腔 鏡手術を施行しえるものと思われた。

\section{PP-386 腹腔鏡下副腎摘除術における疾患別の 比較検討}

\section{浜松医科大学 泌尿器科}

青木 雅信, 影山慎二, 牛山知己, 鈴木 和雄, 藤田 公生 腹腔鏡下副婜摘除術における疾患別の比較検討浜松医科 大学泌尿器科【日的】腹腔鏡下副䁂摘除術について疾患 別の比較を行った。【対象と方法】対象は1992 年 2 月から 2002 年 6 月までに 134 例に施行した腹腔鏡下副腎摘除 術 137 件 (男 68 例, 女 69 例, 平均年齢 50.4 嵅)のうち、 開放手術に移行した 6 例、初期の 20 例を除いた 112 例 で、クッシング症候群 40 例 (プレクッシング症候群を含 む)、褐色細胞腫 9 例、原発性アルドステロン症 35 例の 3 群について、手術時間, 出血量, 術後回復状況, 術後合 併症につき比較検討した。結果】手術時間は 155.7,158.7,155.2 分、出血量は79.6.85.0.54.2mlであり、い ずれも 3 群間に有意差は認めなかった。また、歩行開始 日，食事開始日，退院可能日においても有意差はなかっ た。術後合併症はクッシング症候群で出現した割合が高 かったが、重第なものは認めなかった。考察】良性腫痬 に対する腹腔鏡下副腎摘除術は疾患に関係なく安全に施 行できるが、クッシング症候群に対しては術後合併症に 注意が必要であると考えられた。

\section{PP-387 副腎埂㾤に対する腹腔鏡下副腎摘除術 の臨床的検㷉}

\section{公立南丹病院" 京都府立医科大学 医学部 泌尿器科2) 京都第一赤十字病院 ${ }^{3)}$ 近江八幡市民病院(4) 古賀総合病 院 ${ }^{5)}$}

米田 公彦", 山田 恭弘", 早川 隆啓 ${ }^{51}$, 邵 仁哲 ${ }^{21}$

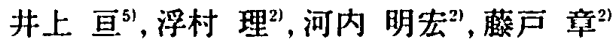

宮下 浩明 ${ }^{4}$, 山崎 悟 ${ }^{3}$, 岩元 則幸 ${ }^{31}$,三木 恒治 ${ }^{21}$

副腎腫度に対する腹腔鏡下副腎摘除術を 51 例に施行し た。患側は右側が 17 例、左側が 34 例で、腫瘍の最大径 は 8 90mm（平均 $29.4 \mathrm{~mm}$ ) であった。開腹術へ移行し た 1 例を除く 50 例で腹腔鏡手術を完遂した。手術時間は 65３40 分 (平均 173 分)、出血量は 10〜350g（平均 72 g)で、輸血を行った症例はなかった。合併症は、腎上極 の梗塞、胆落摘除を必要とした胆落損伤および無気肺を 各々 1 例づつ認めた。経口掑取開始日は翌日〜4日目(平 均 1.5 日目)、歩行開始日は翌日〜 4 日目(平均 1.7 日目)、 鎮痛剂投与期間は 0 5 日間(平均 1.9 日間)、退院可能日 は3〜19 日目 (平均 6.4 日目) であった。これらの成績を それ以前に開放手術を施行した 34 例の成績と比較した 結果、腹腔鏡手術は低侵熋で、術後のQOL が良好な術式 と考えられた。

\section{PP-388 ミニマム創・内視鏡下副罥摘除の成續}

\section{東京医科歯科大学 大学院 尿路生殖㼄能学} 川野 明子, 矢野 雅隆, 小林 剛, 影山幸雄, 兵地 信彦 增田 均, 林 哲夫, 川上 理, 藤井 靖久, 古賀 文隆 大塚 幸宏, 岡田 洋平, 木原和徳 【目的】当科では，摘出する蓸器がようやく通りうる創から， 内視鏡を用いて，炭酸ガスを使用せず，トロッカーポートを 置かない,ミニマム創・内梘鏡下副監摘除を行っているが, 大きな褐色細胞腫以外は，全て腹膜を損偒せず経腰後腹膜 アプローチで行っており，その成績を報告する.【対象・方 法】平成 10 年 7 月より, 平成 14 年 8 月までに行った後腹膜 アプローチ手術 19 例（非活性腺腫 5, Cushing 症候群 6, 原 発性アルドステロン症 5 , 副腎神経節腫 1 , 副腎船 1 , 副腎出 血 1 例, $22 \sim 70$ 才, 中央值 55 才). 経腹膜的手術は褐色細胞 腫の 1 例に行った (61才).【成維】後腹膜手術：腫度径 0.7 $\sim 7 \mathrm{~cm}$, 皮切 4 8cm（中央值 5.5），手術時間 105 183 分 (中央値 143)，出血量 5 372ml（中央値 75），術後歩行開始 日は, 1 2 日 (中央値 1), 術後食事開始日 1 4 日 (中央值 2)であった。経腹膜手術：腫堗径 $7 \mathrm{~cm}$ の下大静脈を圧排す る褐色細胞腫, 皮切 $8 \mathrm{~cm}$ の右季肋下切開で開始し, 操作に よる血圧上昇により順次切開を延長し $15 \mathrm{~cm}$ で終了, 術後 2 日から歩行した。【結詥】ミニマム創・内梘鏡下副腎摘除は， 低侵䧶に行える手術と考えられた。また，襍色細胞腫でも状。 況により適宜創を延長でき安全に手街が行えた。 